\title{
EVALUASI PAJAK HIBURAN TERHADAP PENDAPATAN ASLI DAERAH DI KOTA MANADO
}

\section{Evaluation of Entertainment Tax Affect on Local Revenueof Manado}

\author{
Oleh: \\ Theo Rudolf Waney ${ }^{1}$ \\ Jenny Morasa ${ }^{2}$ \\ Fakultas Ekonomi dan Bisnis Jurusan Akuntansi \\ Universitas Sam Ratulangi \\ Email: ${ }^{1}$ waneytheo@yahoo.com
}

\begin{abstract}
Pendapatan Asli Daerah merupakan satu diantara sumber-sumber pendanaan pemerintah daerah, sangat dibutuhkan dalam melaksanakan tugas pemerintahan maupun pembangunan. Undang-undang tentang pemerintah daerah menetapkan pajak daerah sebagai penerimaan yang berasal dari daerah dapat dikembangkan sesuai kondisi masing-masing daerah. Kota Manado sebagai pusat pemerintahan, perdagangan dan pariwisata memiliki banyak tempat hiburan, karena itu pajak hiburan merupakan satu diantara sumber-sumber pendapatan asli yang penting bagi pemerintah kota Manado. Sejauhmana kontribusi pajak hiburan terhadap pendapatan asli daerah perlu diteliti. Tujuan penelitian adalah mengevaluasi pengaruh pajak hiburan terhadap PAD Kota Manado. Penelitian ini menggunakan data sekunder dari Dinas Pendapatan Daerah Kota Manado. Metode untuk mengevaluasi pengaruh pajak hiburan adalah metode laju pertumbuhan. Data perkembangan pajak hiburan kota Manado antara tahun 2010-2014 memperlihatkan variasi penerimaan pajak hiburan dan belum signifikan mempengaruhi pendapatan asli daerah kota Manado. Variasi penerimaan pajak hiburan kemungkinan besar disebabkan fluktuasi aktivitas hiburan di kota Manado. Penerimaan pajak hiburan yang relatif kecil menunjukkan belum maksimalnya upaya menggali potensi pajak hiburan di kota Manado. Pemerintah kota Manado perlu memberikan kemudahan bagi investasi di sektor-sektor yang berkaitan dengan hiburan dan pada saat yang sama mengoptimalkan penarikan pajak hiburan di Kota Manado. Penelitian selanjutnya perlu memperdalam dan memperluas informasi dan data pajak hiburan di Kota Manado.
\end{abstract}

\section{Kata kunci: pajak, analisis pertumbuhan.}

Local Revenue is among the sources of funding of local government, and is needed in carrying out the task of government and in development. Act 32 of the local government established local tax as one of the local revenue and can be developed according to the conditions of each region. One of the sources of local revenue for the government of the city of Manado is the entertainment tax. Manado city as the center of government, trade and tourism has many places of entertainment, but the extent of the contribution of the entertainment tax on local revenue need to be investigated. The purpose of this study was to evaluate whether the effect of the entertainment tax to the local revenue of Manado. This study used secondary data obtained from the Revenue Affairs of Manado. The method used to evaluate the influence of the entertainment tax is the rate of growth. Data entertainment tax of Manado city between 2010-2014 was analyzed, and it shows the variation of revenue and was not significantly affect local revenues of Manado. Variations in entertainment tax revenues likely caused by fluctuations in entertainment activities in the city of Manado. Tax entertainment revenues are relatively small shows the effort to seek potential entertainment tax are not fully in the city of Manado. The government need to provide facilities for investment in sectors related to entertainment and at the same time optimizeeffort to seek and to collect entertainment tax in the city of Manado. Future studies need to deepen and broaden the acquisition of information and data relating to entertainment tax in the city of Manado.

Keywords :tax, growth analysis. 


\section{PENDAHULUAN}

\section{Latar Belakang}

Pembangunan adalah suatu proses kegiatan yang dilakuan dalaam rangka pengembangkan atau mengadakan perubahan-perubahan kearah keadaan yang lebih baik. Pembangunan yang ingin di capai bangsa Indonesia adalah mewujudkan masyarakat yang adil dan makmur yang merata baik materil maupun spiritual berdaarkan paancasila dan UUD 1945. Demi tercapainya pembangunan nasional, maka penyusunan program pembangunan tersebut mengikuti suatu pola atau tatanan yang telah di tentukan didalam pemerintah negara Indonesia.

Dalam usaha mencapai tujuan pembangunan tersebut, pemerintah menciptakan tahap-tahap pesiapannya, baik untuk jangka panjang maupun jangka pendek yang meliputi perencanaan, pelaksanaan, pembiayaan, pengawasan dan evaluasi dengan tidak mengecilkan arti peran dari pihak-pihak lainnya dalam berpartisipasi mensukseskan pembangunan nasional.

Untuk mendukung pelaksanaan otonomi yang maksimal, pemerintaah mengeluarkan kebijaksanaan dibidang penerimaan daerah yang berorientasi pada urusan rumah tangganya sendiri dan diprioritaskan pada penggalian dana mobilisasi sumber-sumber daerah. Sumber pendapatan daerah menurut UU No. 33 tahun 2004 adalah sebagai berikut.

Pendapatan Asli Daerah (PAD), terdiri dari.

a. Hasil pajak daerah

b. Hasil retribusi daerah

c. Hasil perusahaan milik daerah dan hasil pengelolaan kekayaan daerah yang dipisahkan

d. PAD yang sah

Dana Perimbangan.

Pinjaman daerah.

Lain-lain pendapatan daerah yang sah.

PAD merupakan sumber pendapatan daerah yang secara bebas dapat digunakan oleh masing-masing daerah untuk menyelenggarakan pemerintahan dan pembangunan daerah. Tapi pada kenyataannya kontribusi PAD terhadap pendaptan dan belanja daerah masih kecil. Selama ini dominasi sumbangan pemerintah pusat kepada daerah masih besar.

untuk mengurangi ketergantungan kepada pemerintah pusat, pemerintah daerah perlu berusaha meningkatkan PAD yang salah satunya dengan penggalian potensi Kota Manado merupakan salah satu kota yang ada di Provinsi Sulawesi Utara, guna meningkatkan kemampuannya dalam bidang pendanaan untuk pembangunan. Jenis jenis pajak daerah menurut UU No. 28 tahun 2009 adalah sebagai berikut.

1. Pajak Hotel;

2. Pajak Restoran;

3. Pajak Hiburan;

4. Pajak Reklame;

5. Pajak Penerangan jalan;

6. Pajak Mineral Bukan Logam dan Batuan

7. Pajak Parkir;

8. Pajak Air Tanah;

9. Pajak Sarang Burung Walet;

10. Pajak Bumi dan Bangunan Perdesaan dan Perkotaan; dan

11. Bea Perolehan Hak atas Tanah dan Bangunan.

Di Kota Manado salah satu pajak daerah yang merupakan sumber penerimaan yang potensial apabila dimaksimalkan yaitu meliputi pajak Hiburan. Untuk itu pemerintah perlu berupaya meningkatkan penerimaan pajak hiburan agar penerimaan pemerintah terus meningkat sehingga dapat memperlancar pembangunan. Untuk mencapai ini pemerintah harus melakukan perbaikan dan penyempurnaan dalam bidang keuangan daerah yang 
dikelolah secara efektif dan efisien.

Pemerintah Daerah Kota Manado sebagai pelaksana pemerintahan didaerah secara aktif melakukan upaya pengembangan sumber-sumber pendapatan daerah yang salah satunya adalah pajak hiburan. Berdasarkan pemikiran dan keadaan tersebut maka penulis memilih judul "Evaluasi Pajak Hiburan Pada Pendapatan Asli Daerah Kota Manado"

\section{Tujuan Penelitian}

Tujuan penelitian ini untuk mengetahui seberapa besar pengaruh pajak hiburan terhadap pendapatan asli daerah di kota manado.

\section{TINJAUAN PUSTAKA}

\section{Konsep Akuntansi Pajak}

Mulyono (2006:3), menyatakan bahwa Akuntansi Pajak adalah proses kegiatan pencatatan, dan penyajian dengan cara tertentu atas transaksi keuangan yang terjadi dalam perusahaan/organisasi serta penafsiran terhadap hasilnya.

Mulyono (2006:3), mengemukakan bahwa Akuntansi Pajak adalah akuntansi yang berkaitan dengan perhitungan perpajakan dan mengacu pada peraturan dan perundang-undangan beserta aturan pelaksanaannya.

Mulyono (2006:1), menyatakan bahwa Akuntansi (accounting) merupakan suatu kegiatan yang berfungsi menyediakan informasi kuantitatif terutama yang bersifat keuangan mengenai kesatuan-kesatuan ekonomi tertentu kepada pihak-pihak yang berkepentingan, untuk digunakan sebagai bahan pertimbangan dalam pengambilan keputusan-keputusan ekonomi.

Mulyono (2006:1), mengemukakan bahwa Akuntansi adalah sistem informasi yang mengukur aktivitas bisnis, memproses informasi tersebut menjadi laporan, dan mengkomunikasikan hasilnya kepada para pembuat keputusan

\section{Pendapatan Asli daerah}

Pendapatan asli daerah adalah hak pemerintah daerah yang diakui sebagai penambah nilai kekayaan yang bersih. Definisi PAD menurut Mardiasmo (2000) PAD adalah penghasilan yang dipungut oleh daerah berdasarkan peraturan yang ditetapkan oleh daerah melalui Perda untuk kepentingan rumah tangga pemerintah daerah.

Berdasarkan Undang-Undang No 33 tahun 2004, yang dimaksud dengan PAD adalah “ pendapatan daerah yang bersumber dari hasil pajak daerah, hasil retribusi daerah, hasil pengelolaan kekayaan daerah yang dipisahkan, dan lain-lain PAD yang sah, yang bertujuan untuk memberikan keleluasaan kepada daerah dalam menggali pendanaan dalam pelaksanaan otonomi daerah sebagai perwujudan asas desentralisasi.

Menurut Mardiasmo (2002) bahwah semakin tinggi tingkat investasi modal diharapkan mampu meningkatkan kualitas layanan publik dan gilirannnya mampu meningkatkan tingkat partisipasi (kontribusi) publik terhadap pembangunan yang tercermin daeri adanya peningkatan PAD. Kesinambungan pembangunan daerah semakin lebih terjamin katika publik memberikan tingkat dukungan yang tinggi.

Seragih (2003) menyatakan bahwa setiap peningkatan PAD sebenarnya akses dari pertumbuhan ekonomi, daerah yang pertumbuhan ekonominya positif mempunyai kemungkinan mendapatkan kenaikan PAD.

PAD adalah semua hasil atau jumlah yang diterima / diperoleh pemerintah daerah baik berupa uang tunai atau nilai uang / material lainya dalam suatu tahun anggaran guna untuk membiayai pembangunan dan jalannya pemerintahan daerah dihitung satu tahun anggaran yang bersangkutan.

\section{Pajak Hiburan}

Pajak hiburan adalah pajak atas penyelenggara hiburan, sesuai dengan UU Nomor 28 tahun 2009 pasal 1 angka 24 dan 25. Yang dimaksud pajak hiburan itu sendiri adalah semua jenis tontonan, pertunjukan, permainan, dan atau keramayaian yang dinikmati dengan dipungut bayaran. Pemungutannya tidak mutlak ada pada seluruh daerah kabupaten atau kota yang ada di Indonesia, sehingga pemerintah pemerintah daerah setempat harus mengeluarkan peraturan daerah tentang pajak hiburan. berikut:

Dalam pemngutan pajak hiburan terdapat beberapa terminologi yang perlu diketahui, yaitu sebagai 
1. Hiburan adalah semua jenis tontonan, pertunjukan, permainan dan atau keramaian yang dinikmati dengan dipungut bayaran.

2. Penyelenggara hiburan adalah orang pribadi atau yang bertindak baik untuk atas namanya sendiri atau untuk dan atas nama pihak lain yang menjadi tanggungannya dalam menyelenggarakan suatu hiburan.

3. Penonton atau pengunjung adalah setiap orang yang menghadiri suatu hiburan untuk melihat dan atau mendengar atau menikmatinya atau menggunakan fasilitas yang disediakan oleh penyelenggara hiburan, kecuali penyelenggara, karyawan, artis(para pemain), dan petugas yang menghadiri untuk melakukan tugas pengawasan.

4. Pembayaran adalah jumlah yang diterima atau seharusnya diterima dalam bentuk apa pun untuk harga pengganti yang diminta atau seharusnya diminta wajib pajak sebagai penukar atas pemakain dan atau pembelian jasa hiburan serta fasilitas penunjangnya termasuk pula semua tambahan dengan nama apa pun juga yang dilakukan oleh WP yang berkaitan langsung dengan penyelenggaraan hiburan.

5. Tanda masuk adalah semua tanda atau alat atau cara yang sah dengan nama dan dalam bentuk apapun yang dapat digunakan untuk penonton, menggunakan fasilitas, atau menikmati hiburan. tanda masuk disini adalah misalnya karcis, tiket undangan, kartu langganan, kartu anggota, dan sejenisnya

6. Harga tanda masuk, yang selanjutnya disingkat HTM, adalah nilai uang yang tercantum pada tanda masuk yang harus dibayar oleh penonton atau pengunjung.

\section{Penelitian Terdahulu}

Sariambong (2010) dengan penelitian mengenai analisis pengaruh pajak hotel, restoran dan hiburan terhadap pendapatan asli daerah di kota tomohon. Adapun tujuan penelitian adalah untuk menganalisis pajak hotel, restoran dan hiburan terhadap PAD kota tomohon. Penelitian yang dilakukan mengguanakan metode penelitian kuantitatif. Terdapat persamaan dengan penelitian ini yakni pada tujuannya yaitu untuk menganalisis pajak hotel, restooran dan hiburan terhadap PAD di kota tomohon. Perbedaannya peneliti sebelumnya menggunakan metode kuantitatif, sedangkan penelti sendiri menggunakan metode pengembangan deskripsi.

Nurdin (2012) dengan penelitian mengenai analisis potensi pengaruh pajak hotel, restoran dan hiburan terhadap PAD. Penelitian ini bertujuan untuk mengetahui seberapa besar realisasi penerimaan PAD dari sektor pajak hotel, restoran dan hiburan. Penelitian yang dilakukan menggunakan metode analisis deskriptif. Adapun persamaan penelitian ini terdapat pada metode yang sama, sedangkan perbedaannya terletak pada objek penelitian.

\section{METODE PENELITIAN}

\section{Jenis Penelitian}

Jenis penelitian yang digunakan penulis pada penelitian ini adalah penelitian deskriptif. Sekaran (2009:105), mendefinisikan a descriptive study is undertaken in order to ascertain an be able to describe the characteristics of the variables of interest in a situation. Dengan demikian penelitian deskriptif adalah penelitian yang menggambarkan dan mendeskripsikan suatu keadaan dalam bentuk data dan menganalisa data tersebut.

\section{Tempat dan Waktu Penelitian}

Adapun penelitian ini dilakukan di Kota Manado yaitu pada dinas pendapatan daerah Kota Manado. Dengan waktu penelitian dimulai sejak bulan Desember 2014

\section{Prosedur Penelitian}

Langkah - langkah yang di lakukan dalam penelitian ini sebagai berikut:

1. Mengajukan Permohonan Penelitian

2. Pengumpulan Data

3. Analisa Data Penelitian

4. Kesimpulan dan Saran.

\section{Metode Pengumpulan Data}


Dalam usaha memperoleh data dan informasi yang berkenaan dengan penelitian ini untuk dijadikan sebagai bahan atau materi pembahasan maka metode pengumpulan data yang dilakukan adalah pengumpulan data kuantitatif dan kualitatif dan studi kepustakaan.Data kuantitatif adalah data yang diukur dalam suatu skala numerik (Kuncoro 2009 : 145). Data kualitatif yang digunakan berupa gambaran umum DISPENDA MANADO, sejarah berdirinya instansi, struktur organisasi, dan lain sebagainya.

Dalam penelitian ini, berdasarkan sumbernya data dapat dibedakan menjadi :

1. Data primer

Merupakan data yang diperoleh dari sumber aslinya. Data primer dalam penelitian ilmiah selain survei yaitu observasi langsung, yaitu proses pencatatan pola perilaku subyek (orang), obyek (benda) atau kejadian yang sistematik tanpa adanya pertanyaan atau komunikasi dengan individu-individu yang diteliti. Data primer merupakan data yang dikumpulkan oleh perorangan atau organisasi perusahaan yang merupakan obyek penelitian dimana data tersebut merupakan data yang belum di olah dan di ambil langsung.

2. Data sekunder

Data sekunder adalah data yanng telah dikumpulkan oleh pihak lain (Kuncoro, 2009 : 145). Data sekunder yang diambil, diperoleh dari hasil literatur kuliah, makalah jurnal, serta literatur-literatur lainnya yang berhubungan dengan penelitian serta referensi lainnya yang relevan dengan penelitian ini. Sumber data dan penelitian ini adalah pajak hiburan dan PAD kota manado dari tahun 2010 sampai dengan 2014.

\section{Metode Analisis}

Metode analisis data yang digunakan dalam penelitian ini adalah deskriptif. Dalam analisis data deskriptif, peneliti hanya terbatas pada, perhitungan, dan mengumpulkan, menyusun, mengolah, serta menganalisis data angka, agar dapat memberikan gambaran mengenai suatu keadaan tertentu sehingga dapat ditarik kesimpulan.

Untuk menghitung pertumbuhan pajak hiburan terhadap PAD di Kota Manado dalam ukuran waktu 2010 sampai dengan 2014 maka digunakan rumus sebagai berikut

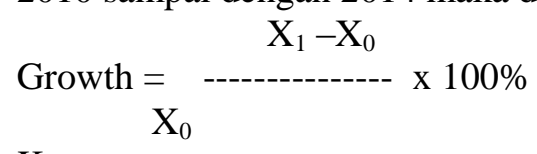

Keterangan

Growth $=$ Pertumbuhan pajak hiburan

$\mathrm{X}_{1} \quad=$ PAD Tahun Sekarang

$\mathrm{X}_{0} \quad=$ PAD Tuhun Sebelumnya

\section{HASIL PENELITIAN DAN PEMBAHASAN}

\section{Hasil Penelitian \\ Sejarah Singkat Disnas Pendapatan Asli Daerah Kota Manado}

Dinas Pendapatan (Dipenda) kota manado di bentuk berdasarkan Perda NO.4 tahun 2002. Tugas poko dari Dipenda Kota Manado adalah melaksanakan kewenangan otonomi daerah Kota Manado dalam rangka pelaksanaan tugas Desentralisasi. Fungsi dari Dipenda Kota Manado adalah sebagai berikut.

A. Perumusan kebijakan teknis pendapatan daerah ;

B. Pelaksanaan pelayan umum;

C. Pembinaan terhadap unit pelaksanaan teknis Dinas dalam pendapatan daerah; dan

D. Pelaksana tugas pokok sesuai kebijakan yang di tetapkan

\section{Visi dan Misi Dinas Pendapatan Kota Manado}

A. Visi Dipenda adalah Terwujudnya pengelolaan pendapatan daerah untuk meningkatkan penerimaan dan pelayanan

B. Dalam mewujudkan visi tersebut, maka dirumuskan misi yaitu.

1. Meningkatkan penerimaan sumber-sumber potensi pendapatan daerah:

2. Meningkatkan pelayanan kepada masyarakat;

3. Mengembangkan koordinasi secara sinergis dan pengelolaan pendapatan daerah; dan

4. Meningkatkan dan mengembangkan sumber daya aparatur pendapatan daerah. 


\section{Perkembangan Penerimaan Pajak Hiburan Dipenda Kota Manado}

Berikut ini adalah tabel target dan realisasi penerimaan pajak hiburan di Dipenda Kota Manado pada tahun 2010 sampai dengan 2014

Tabel 1 Target dan Realisasi Penerimaan Pajak Hiburan pada Dinas Pendapatan Kota Manado tahun 2010 sampai dengan 2014

\begin{tabular}{cccc}
\hline Tahun & Target pertahun & Realisasi & Capaian \\
\hline & $($ Rp $)$ & $($ Rp $)$ & $(\%)$ \\
\hline 2010 & 2.526 .000 .000 & 2.897 .097 .211 & 14,69 \\
\hline 2011 & 3.625 .000 .000 & 3.389 .256 .027 & $-6,50$ \\
\hline 2012 & 4.200 .000 .000 & 5.498 .904 .721 & 30,93 \\
\hline 2013 & 7.000 .000 .000 & 7.195 .289 .512 & 2,79 \\
\hline 2014 & 7.349 .999 .850 & 7.280 .563 .807 & $-0,94$ \\
\hline
\end{tabular}

\section{Sumber : Dinas Pendapatan Daerah}

Menjelaskan pada tabel 1 realisasi pajak hiburan pada tahun 2010 sebesar Rp. 2.897.097.211 atau sebesar 14,69 \% dari target yang di rencanakan dari awal hanya Rp. 2.526.000.000. Selanjutnya pada tahun 2011 realisasi pajak hiburan sebesar Rp. 3.389.256.027 atau sebesar -6,50\%. Dan pada tahun 2012 realisasi pajak hiburan sebesar Rp. 5.498.904.721 atau sebesar 30,93\%. Selanjutnya ditahun 2013 realisasi pajak hiburan sebesar Rp.7.195.289.512 atau sebesar 2,79\%. Kemudian pada tahun 2014 realisasi pajak hiburan sebesar Rp. 7.280.563.807atau sebesar $-0,94 \%$ yang pada tahun ini mengalami penurunan pendapatan yang harusnya target pada tahun 2014 adalah Rp. 7.349.999.850 sehingga pencapaian padah tahun 2014 sebesar $-0,94 \%$

\section{Pembahasan}

Untuk menghitung laju pertumbuhan pajak hiburan untuk tahun 2010 sampai 2014 dapat dilihat pada table2 berikut.

Tabel 2 perkembangan Penerimaan Pajak Hiburan di Kota Manado Tahun 2010 sampai 2014

\begin{tabular}{ccccc}
\hline TAHUN & TARGET & GROWTH & REALISASI & GROWTH (\%) \\
& $(\mathbf{R p})$ & $(\boldsymbol{\%})$ & $(\mathbf{R p})$ & \\
\hline $\mathbf{2 0 1 0}$ & 2.525 .000 .000 & - & 2.897 .097 .211 & - \\
\hline $\mathbf{2 0 1 1}$ & 3.625 .000 .000 & 43,50 & 3.389 .256 .027 & 16,98 \\
\hline $\mathbf{2 0 1 2}$ & 4.200 .000 .000 & 18,66 & 5.498 .904 .721 & 62,24 \\
\hline
\end{tabular}




\begin{tabular}{lrrcc}
\hline $\mathbf{2 0 1 3}$ & 7.000 .000 .000 & 66,66 & 7.195 .289 .512 & 30,84 \\
\hline 2014 & 7.349 .999 .850 & 4,99 & 7.280 .563 .807 & 1,18 \\
\hline
\end{tabular}

\section{Sumber: Dinas Pendapatan Daerah}

Menjelaskan tabel2 di atas dapat di ketahui baahwa pertumbuhan pajak hiburan terhadap PAD di Kota Manado untuk tahun 2011 sebesar 16,98\% terjadi penurunan penerimaan pajak hiburan. Hal ini sebabkan karena banya masyarakat lebih memilih hiburan yang tidak mengeluarkan biaya/uang. Contohnya banyak masyarakat kota manado lebih memilih tempat hiburan yang berada di mall dari pada tempat hiburan karoke, billiard dll. Karena tempat hiburan seperti mall tidak mengeluarkan biaya dan cukup nyaman yang dapat di nikmati. Ini berarti pertumbuhan penerimaan pajak hiburan terhadap PAD di Kota Manado berkurang. Selanjutnya pada tahun 2012 sebesar 62,24\% ini berarti pertumbuhan penerimaan pajak hiburan terhadap PAD di Kota manado meningkat karena petugas penagih pajak hiburan lebih memperketat penagagihannya, sehingga penerimaan pajak hiburan pada tahunn 2012 meningkat. Dengan demikian pertumbuhan pajak hiburan dari tahun 2011 sampai 2012 meningkat sebesar 62,24\%. Dan merupakan tingkat pertumbuhan yang sangat besar dalam kurun waktu 2010-2014. Selanjutnya pada tahun 2013 pertumbuhan pajak hiburan menurun sebesar 30,84\%. Selanjutnya pada tahun 2014 sebesar 1,18\% dan pada tahun ini penerimaan pajak hiburan paling rendah dari tahun-tahun sebelumnya.

\section{PENUTUP}

\section{Kesimpulan}

Hasil penelitian pajak hiburan dari tahun 2010 sampai 2014 mengalami peningkatan yang cukup signfikan pada tahun 2011. Meskipun penerimaan pajak hiburan tidak memenuhi target tetapi secara jumlah penilaian dari tahun 2010 sampai dengan 2014 adalah meningkat.

Perkembangan penerimaan pajak hiburan dikota Manado masih rendah, ini disebabkan masih kurangnya tempat hiburan yang ada dikota Manado. Tempat hiburan yang ada dikota Manado lebih banyak pada tempat yang bersifat karouke, pub, billyard dll yang hanya untuk kalangan tertentu. Sedangkan sebagian besar masyarakat kota Manado lebih memilih tempat hiburan yang lain tidak mengeluarkan biaya.

\section{Saran}

Dari kesimpulan yang dibuat maka penelitian ini dapat memberikan saran untuk dapat disajikan sebagai bahan pertimbangan dalam memberikan kebijakan pemerintah kota manado. Penerimaan pajak hiburan pada tahun 2010 sampai 2014 dikota Manado masih dapat ditingkatkan. Oleh karena itu untuk meningkatkan penerimaan pajak hiburan pemerintah kota manado meningkatkan penagihan pajak hiburan di setiap saran pajak hiburan dan menambah sarana hiburan seperti taman hiburan yang cocok untuk semua kalangan. Contohnya seperti Dufan, taman impian Ancol dan lain sebagainya yang ada di jakarta

\section{DAFTAR PUSTAKA}

Ahmed Riahi-Belkaoui.2011. Teori Akuntansi. : Salemba Empat, Jakarta

Harahap, Sofyan Syafri. 2005 . Teori Akuntansi. Penerbit PT. Raja Grafindo Persada: Jakarta.

Mardiasmo. 2006. Perpajakan, Edisi Revisi 2006, Yogyakarta.

Mardiasmo, 2011, Perpajakan Edisi Revisi 2009, ANDI, Yogyakarta. 
Republik Indonesia. 2004. Undang-Undang No.32 Tahun 2004 Tentang Pemerintah Daerah, Jakarta.

Republik Indonesia. 2004. Undang-Undang No.33 Tahun 2004 Tentang Pajak Daerah dan Pajak Retribusi, Jakarta

Siahaan, Marihot P. 2005. Pajak Daerah Dan Retribusi Daerah, Edisi 1. Penerbit PT. Raja Grafindo Persada. Jakarta

Soemitro, R.2006. Asas dan Dasar Perpajakan . PT. Eresco Bandung.

Sunarto, 2003. Perpajakan I. Penerbit AMUS Yogyakarta dan Mahareiko Total Design. Yogyakarta.

Siti, Resmi. 2011, Perpajakan, Teori dan Kasus Edisi Revisi 2011, Salemba Empat, Jakarta.

Waluyo. 2011, Perpajakan Indonesia Edisi Revisi 2011, Salemba Empat, Jakarta

Waluyo. 2006. Perpajakan Indonesia, Edisi 6. Penerbit Salemba Empat. Jakarta.

Wirawan B. Ilyas, Richard Burton, 2010. Hukum Pajak. edisi 5.:Salemba Empat, Jakaarta

Sariambong , Indri. 2010. Analisis Pengaruh pajak Hotel, Restoran dan Hiburan Terhadap Pendapatan Asli Kota Manado. Universitas Samratulangi Manado. 